\title{
Mechanistic Insight into Disinfection Using Ferrate(VI)
}

\author{
Djamel Ghernaout ${ }^{1,2 *}$, Noureddine Elboughdiri1,3 \\ ${ }^{1}$ Chemical Engineering Department, College of Engineering, University of Ha'il, Ha'il, KSA \\ ${ }^{2}$ Chemical Engineering Department, Faculty of Engineering, University of Blida, Blida, Algeria \\ ${ }^{3}$ Département de Génie Chimique de Procédés, Laboratoire Modélisation, Analyse, et Commande des systèmes, Ecole Nationale \\ d’Ingénieurs de Gabès (ENIG), Rue Omar Ibn-Elkhattab, Gabès, Tunisia \\ Email: ^djamel_andalus@hotmail.com
}

How to cite this paper: Ghernaout, D. and Elboughdiri, N. (2019) Mechanistic Insight into Disinfection Using Ferrate(VI). Open Access Library Journal, 6: e5946.

https://doi.org/10.4236/oalib.1105946

Received: November 22, 2019

Accepted: November 30, 2019

Published: December 3, 2019

Copyright $\odot 2019$ by author(s) and Open Access Library Inc.

This work is licensed under the Creative Commons Attribution International License (CC BY 4.0).

http://creativecommons.org/licenses/by/4.0/

\begin{abstract}
Disinfection, chemical oxidation, and coagulation are key methods in water treatment. A chemical that may be used for all these targets is ferrate(VI). This work tries to bring some light into mechanisms implied throughout killing microbes using ferrate(VI). In acidic $\mathrm{pH}$, the oxidation and reduction capacity of ferrate(VI) is superior to all currently utilized oxidizers and disinfectants in water and wastewater treatment. The technology of using ferrate(VI) for coagulation, chemical oxidation and disinfection of water and wastewater in a reactor simultaneously, can reduce the size of water and wastewater treatment plants and increase the treatment efficiency. Ferrate(VI) allows a novel emergency water treatment design for disaster-affected populations through the repercussions of natural disasters, through the concurrent and efficient elimination of microbial and chemical pollutants. The ferrates' elevated performance and utilization as a green element for water treatment propose that these techniques remain greatly convenient for usage as pre- or post-treatment in traditional wastewater plants. It seems that there is no big difference in terms of ferrate's action on pathogens with other chemical disinfectants. However, ferrate was found to be requiring lower needed doses as compared with other chemicals. More researches on disinfection by-products formation following ferrate injection as a disinfectant are required. Finally, ferrate(VI) deserves more attention to be used more largely through worldwide wastewater treatment plants.
\end{abstract}

\section{Subject Areas \\ Chemical Engineering \& Technology}

\section{Keywords}

Ferrate, Wastewater Treatment, Drinking Water, Disinfection, Green 
Technology, Iron

\section{Introduction}

During the last decades, iron-founded nanoparticles have reached augmented attention for environmental treatment usages [1]-[8]. Their employment in dealing with polluted water has been particularly classified as an extremely interesting option for eliminating biotic and abiotic pollutants [9]. Among these, ferrates are viewed as a significant category of iron-founded materials that possess singular physical-chemical characteristics with crucial capacity for treating water [10] [11].

Ferrate possesses exceptional redox potential and its application has been found to augment under acidic $\mathrm{pH}$ [9]. It is well known that it is an outstanding oxidizing chemical that is useful in performing coagulation actions via constituting ferric hydroxide during the reactional mechanism [12] [13] [14] [15]. The objective of this work is to discuss the application of ferrate-like chemicals as killing agents and routes implied in their functions. Moreover, future trends and primary dares to largely employ ferrate are also exhibited.

This work tries to bring some light into routes involved during killing microbes using ferrate(VI).

\section{Employing Ferrate as Disinfectant}

In water disinfection field, ferrate has been widely examined and has been found to be an exceptional killing agent [9]. Apart from employing it to demobilize bacteria (Escherichia coli, Salmonella, Staphylococcus aureus, Bacillus sp., Pseudomonas sp., Enterococcus faecalis) in water [16] [17] [18] [19], ferrate has also been utilized for attractive implementations like demobilizing fish parasites (Ichthyophthirius multifiliis) [20] and eliminating harmful algae (such as $\mathrm{Mi}$ crocystis aeruginosa) [19] [21] and viruses [22]. Former publications illustrate that the disinfection potential of ferrate augments greatly at $\mathrm{pH}$ degrees lower than 8.0 thanks to protonated ferrate species (Figure 1). This implies that it may demobilize most of the pathogenic microorganisms aforesaid employing doses as low as $1 \mathrm{mg} / \mathrm{L}[23]$.

For water disinfection estimates, ferrate was found to be greatly influenced by temperature. Indeed, researchers [22] observed that the ferrate demobilization rate constants for coliphage MS2 augmented by up to fourfold via elevating the temperature from $5^{\circ} \mathrm{C}$ to $30^{\circ} \mathrm{C}$ (Figure 2). The impact of temperature on the demobilization operation of MS2 was established to fit with the Arrhenius equation, and a dependence resulting from changing oxidation pathways and/or initial attack sites on the MS2 phage protein or genome components has been proposed [9]. Nevertheless, the influence of temperature is complex since various investigations have mentioned marginal or no impact of temperature for the demobilization of MS2 and Bacillus subtilis spores employing ferrate [24]. 


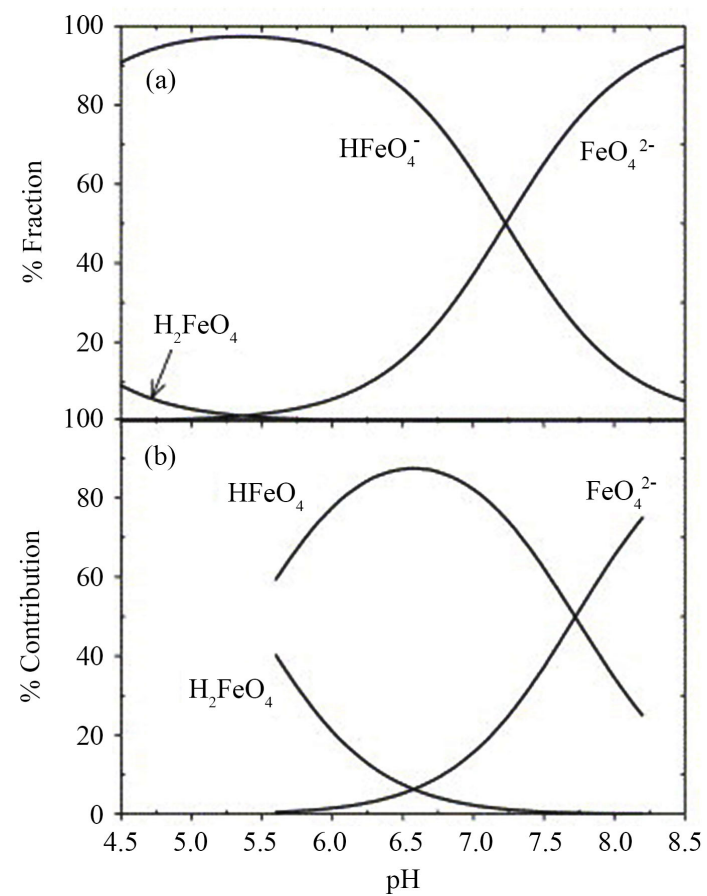

Figure 1. (a) Distribution of $\mathrm{Fe}(\mathrm{VI})$ species as a function of $\mathrm{pH}$. (b) Percent contribution from each $\mathrm{Fe}(\mathrm{VI})$ species $\left(\mathrm{H}_{2} \mathrm{FeO}_{4}, \mathrm{HFeO}_{4}^{-}\right.$, and $\left.\mathrm{FeO}_{4}^{2-}\right)$ to overall E. coli inactivation as a function of $\mathrm{pH}$ [16].
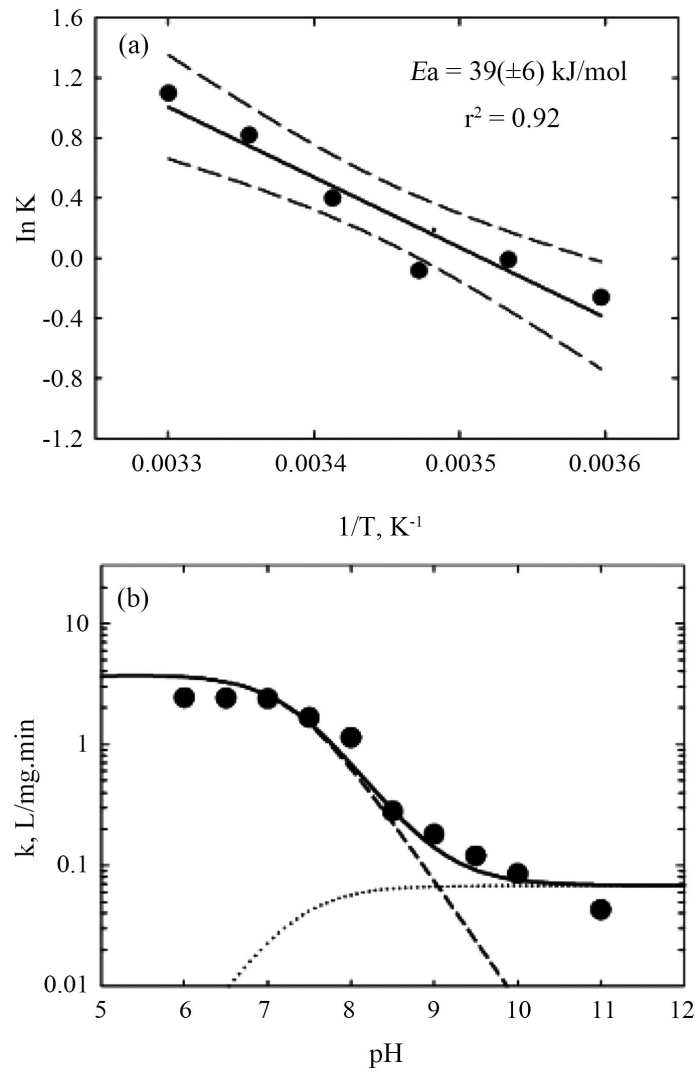

Figure 2. Effect of (a) temperature and (b) $\mathrm{pH}$ on the kinetics of MS2 inactivation using ferrate [22]. 
On the other hand, $\mathrm{pH}$ was likewise observed to significantly influence ferrate-founded disinfection techniques. More important demobilization rate constants were determined for the disinfection method of MS2 at a lower pH and the identical was noticed to be correct for E. coli demobilization [17]. It has been proposed that the impact of $\mathrm{pH}$ on the disinfection efficiency may be linked to the dependence of the reactivity of $\mathrm{Fe}(\mathrm{VI})$ on acid-base speciation. For $\mathrm{pH}$ comprised between 5 and 8, ferrate is distinguished by two conjugate pairs (Equations (1) and (2)) [9]:

$$
\begin{gathered}
\mathrm{H}_{2} \mathrm{FeO}_{4} \leftrightarrow \mathrm{H}^{+}+\mathrm{HFeO}_{4}^{-} \quad p \mathrm{~K}_{\mathrm{a} 1}=3.5 \\
\mathrm{HFeO}_{4}^{-} \leftrightarrow \mathrm{H}^{+}+\mathrm{FeO}_{4}^{2-} \quad p \mathrm{~K}_{\mathrm{a} 2}=7.3
\end{gathered}
$$

Researchers [25] [26] [27] proposed that protonated ferrate species (Equation (1)) are more powerful oxidants than non-protonated species as protonation decreases the electron-donating potential of the coordinated oxygen ligands encouraging metal center to serve with more elevated oxidative potential [9] [28].

Employing ferrate as a preoxidant for natural organic matter (NOM) [29] [30], reports have mentioned that the generation of THMs was decreased through water disinfection if it is pursued by chlorination [31] [32] [33]. Nevertheless, it has also been mentioned that small injections of ferrate $(1 \mathrm{mg} / \mathrm{L}$ as $\mathrm{Fe})$ may produce chloral hydrate and halo ketones; while more elevated injections (20 $\mathrm{mg} / \mathrm{L} \mathrm{Fe}$ ) importantly diminish the generation of such by-products [34].

In tertiary treated wastewater [35]-[41], big-scale ferrate disinfection has been mentioned to together eliminate total organic carbon (TOC) and pathogens from water (Figure 3) [9] [42]. A configuration was suggested to support coagulation besides the oxidation reaction thanks to its reduction potential, as illustrated in Equations (3) and (4) [42]:

$$
\begin{gathered}
\mathrm{FeO}_{4}^{2-}+8 \mathrm{H}^{+}+3 \mathrm{e}^{-} \rightarrow \mathrm{Fe}^{3+}+4 \mathrm{H}_{2} \mathrm{O} \quad E^{\circ}=+2.20 \mathrm{~V} \\
\mathrm{FeO}_{4}^{2-}+4 \mathrm{H}_{2} \mathrm{O}+3 \mathrm{e}^{-} \rightarrow \mathrm{Fe}(\mathrm{OH})_{3}+5 \mathrm{OH}^{-} \quad E^{\circ}=+0.72 \mathrm{~V}
\end{gathered}
$$

Figure 3(a) illustrates the findings acquired for TOC elimination employing $\mathrm{Fe}(\mathrm{VI})$ contrasted with employing hypochlorite as a traditional oxidizer. As displayed, TOC elimination was a fair function of the oxidant concentration and a more important ferrate concentration conducted to a more elevated TOC decrease, perhaps due to the concurrent presence of ferrate-formed coagulation and an oxidative/reductive process [16] [42]. The more elevated TOC elimination was attained employing $14 \mathrm{mg} / \mathrm{L}$ of ferrate (like $48 \%$ TOC decrease) following one hour of reaction, while less than half of the TOC was eliminated employing the identical reaction circumstances for chlorine. The most important finding was that ferrate was also capable of jointly demobilize pathogens even with reacting with organic matter in the wastewater. Figure $3(\mathrm{~b})$ presents the demobilization of total and fecal coliforms employing ferrate (circles) and hypochlorite (triangles). Figure 3 (b) displays that ferrate was apt to demobilize up to 4-log units employing disinfectant injection $(C \times t)$ values under 20 $(\mathrm{mg} / \mathrm{L}) \cdot \mathrm{min}$, while $C \times t$ values bigger than $120(\mathrm{mg} / \mathrm{L}) \cdot \mathrm{min}$ of hypochlorite were required to obtain the identical demobilization levels [9]. 

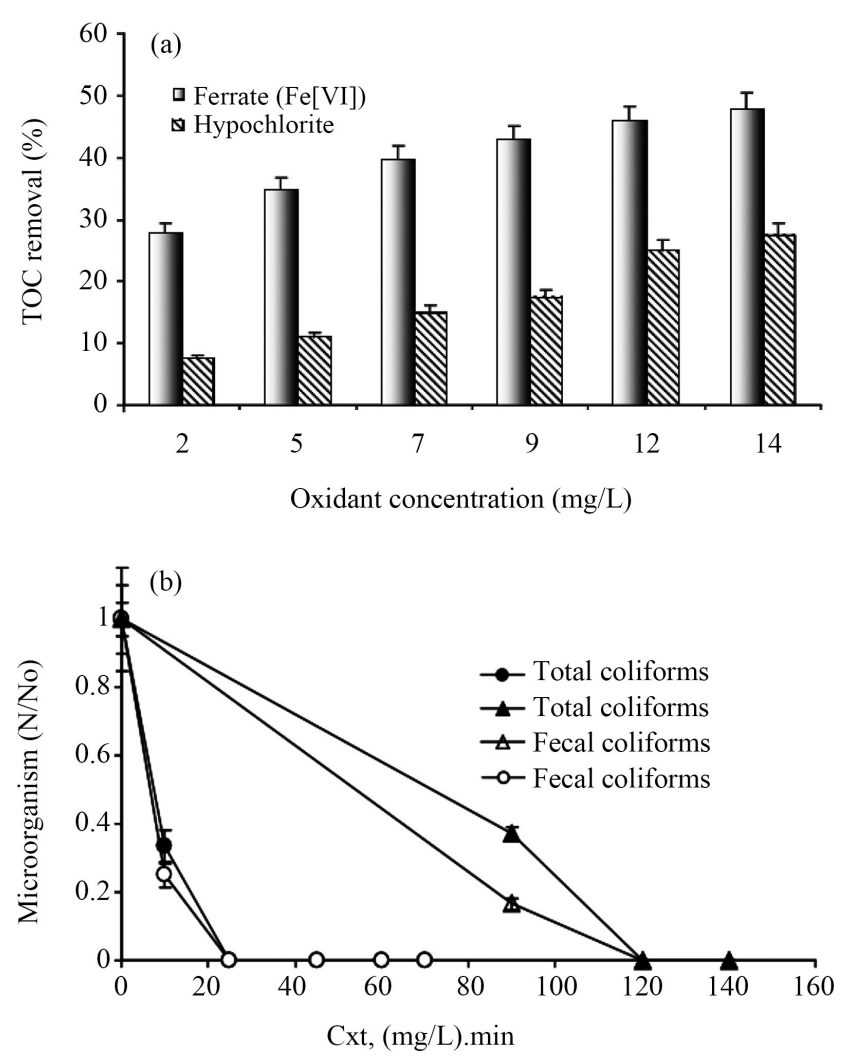

Figure 3. Simultaneous removal of TOC (a) and total and fecal coliforms (b) in wastewater using ferrate (circles) and hypochlorite (triangles) [42].

\section{Ferrate(VI) for Emergency Water Treatment (EWT)}

Cui et al. [43] performed bench-scale trials to estimate ferrate(VI) for treating simulated disaster-polluted water. They proved that ferrate(VI) treatment can together and efficiently demobilize microbial parameters, eliminate metal and metalloid pollutants, decompose dissolved organic matter, and decrease turbidity, whereas insignificantly augmenting total dissolved solids (TDS) to guarantee an allowable TDS $\leq 1000 \mathrm{mg} / \mathrm{L}$ (the recommended minimum TDS standard for an emergency water supply) [43]. The ferrate(VI) injection possessed a fundamental contribution, as it immediately affected the elimination rates and also influenced the size distributions of iron [44] [45] and metal/metalloid pollutants after treatment. As the ferrate(VI) injection augmented, the portions of soluble and colloidal iron and metal/metalloid pollutants diminished, whilst their particulate fractions augmented, indicating that the pollutants were fixed with ferrate(VI) resultant iron particles. Consequently, an elevated ferrate(VI) injection could quicken the aggregation of fine iron particles, that way helping the elimination of fixed toxic metals and metalloids in resulting solid-liquid separation. Ferrate(VI) reveals a novel chance for emergency water treatment (EWT) to supply secure and sufficient water for disaster-affected populations. The comprehension may be used to ferrate(VI) treatment design for urban water treatment [46] [47] [48] and reuse (Figure 4). 


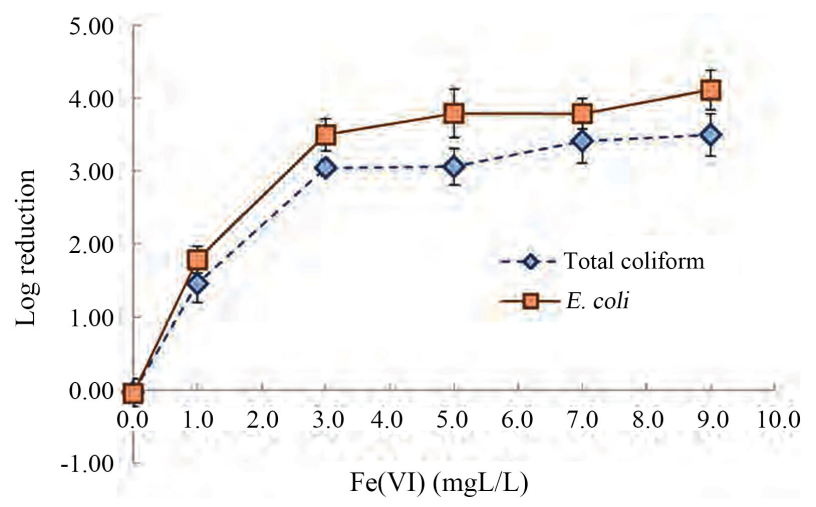

Figure 4. Removals of total coliforms and E. coli at various ferrate(VI) injections during the ferrate(VI) treatment of sewage polluted surface water [43].

\section{Demobilizing Bacillus subtilus Spores via $\mathrm{UV} / \mathrm{H}_{2} \mathrm{O}_{2} /$ Ferrate Hybrid Process}

Despite the fact that chlorination possesses the capacity to demobilize most of the microbes in water, protozoan parasites such as $C$. parvum oocysts and Giardia cysts may fight against it. Consequently, several scientists focused on searching new method for disinfecting water more efficiently [49] [50] [51]. Matin et al. [52] assessed the interactive impact of $\mathrm{H}_{2} \mathrm{O}_{2}$ and ferrate pursued via UV radiation to demobilize Bacillus subtilis spores as surrogate microbes. They used response surface methodology (RSM) in optimizing $\mathrm{UV} / \mathrm{H}_{2} \mathrm{O}_{2} /$ ferrate and $\mathrm{H}_{2} \mathrm{O}_{2}$ /ferrate techniques. Through employing central composite design (CCD), the impact of three major factors comprising time, hydrogen peroxide, and ferrate concentrations was estimated on process efficiency. Their findings displayed that integrating $\mathrm{UV}, \mathrm{H}_{2} \mathrm{O}_{2}$, and ferrate was the most efficient disinfection technology [53] [54] [55] [56] [57] comparatively with $\mathrm{H}_{2} \mathrm{O}_{2}$ and ferrate. They established that via $\mathrm{UV} / \mathrm{H}_{2} \mathrm{O}_{2} /$ ferrate, around $5.2 \mathrm{log}$ reductions of $B$. subtilis spores were attained at $9299 \mathrm{mg} / \mathrm{L}$ of $\mathrm{H}_{2} \mathrm{O}_{2}$ and $0.4 \mathrm{mg} / \mathrm{L}$ of ferrate concentrations following $57 \mathrm{~min}$ of residence period, which was the best circumstance (Figure 5). However, $\mathrm{H}_{2} \mathrm{O}_{2}$ /ferrate may demobilize $B$. subtilis spores around 4.7 logs comparatively with the other method. Consequently, these findings proved that $\mathrm{UV} / \mathrm{H}_{2} \mathrm{O}_{2} /$ ferrate technique is an encouraging method for both demobilizing spores and disinfecting water.

\section{Ferrate as a Coagulant}

In its environmental usages [58], coagulation and chemical oxidation have long been known as two main pathways of ferrate(VI) (i.e. $\mathrm{FeO}_{4}^{2-}$, an oxyanion holding $\mathrm{Fe}(\mathrm{VI})$ ). Even if ferrate(VI) oxidation of different pollutants has been widely investigated, fewer works were performed to evaluate the routes and comportments of ferrate(VI)-driven coagulation in water. Lv et al. [59] examined coagulation of colloidal kaolin particles using ferrate(VI) in simulated natural water under the circumstances regarding potable water treatment (initial turbidity $25.00 \mathrm{NTU}, 0.0-9.0 \mathrm{mg} / \mathrm{L} \mathrm{Fe}(\mathrm{VI}), \mathrm{pH} 7.5$, and $0.50-10.00 \mathrm{mg} / \mathrm{L}$ 
DOC). Fe(III) generated from $\mathrm{Fe}(\mathrm{VI})$ reduction launched in situ coagulation. Minimal efficient iron doses (MEIDs) were detected for $\mathrm{Fe}(\mathrm{VI})$ coagulation than for direct Fe(III) coagulation at $\mathrm{pH} 6.5$ and $7.5(\mathrm{DOC}=2.00 \mathrm{mg} / \mathrm{L})$, at which the colloids were fixed by iron precipitates mainly by sweep coagulation [60] [61]. They employed a citrate-ascorbate iron extraction technique to show that $\mathrm{Fe}(\mathrm{VI})$ consequent flocs were constituted of both amorphous and crystalline iron with an amorphous to crystalline Fe ratio of around 2.3:1.0 (pH 7.5, $3.0 \mathrm{mg} / \mathrm{L} \mathrm{Fe}(\mathrm{VI})$, and $2.00 \mathrm{mg} / \mathrm{L}$ DOC). Ferrate(VI) oxidation converted NOM preferentially into more hydrophilic components [62], which possess a lower affinity with colloids and therefore are less adsorbed on colloids to form a less negatively charged surface. Consequently, ferrate(VI) oxidation greatly enhanced the aggregation of colloids via the mitigation of electrostatic repulsion. Nevertheless, NOM at an elevated concentration ( $8.00-10.00 \mathrm{mg} / \mathrm{L}$ DOC) may avoid the agglomeration of small iron oxide particles by the generation of a negatively charged NOM coating through adsorption, that way avoiding the development of flocs (Figure 6). If integrated with ferrate(VI) oxidation, ferrate(VI) coagulation gives a more usable treatment solution to remedy numerous water pollution in raw water, like the existence of algal cells and dissolved algal toxins [63] [64] [65] [66] in water throughout a harmful algal bloom [67]. The twin treatment routes authorize an extremely efficient treatment design with an economical physical footprint for supporting a sustainable municipal drinking water supply.
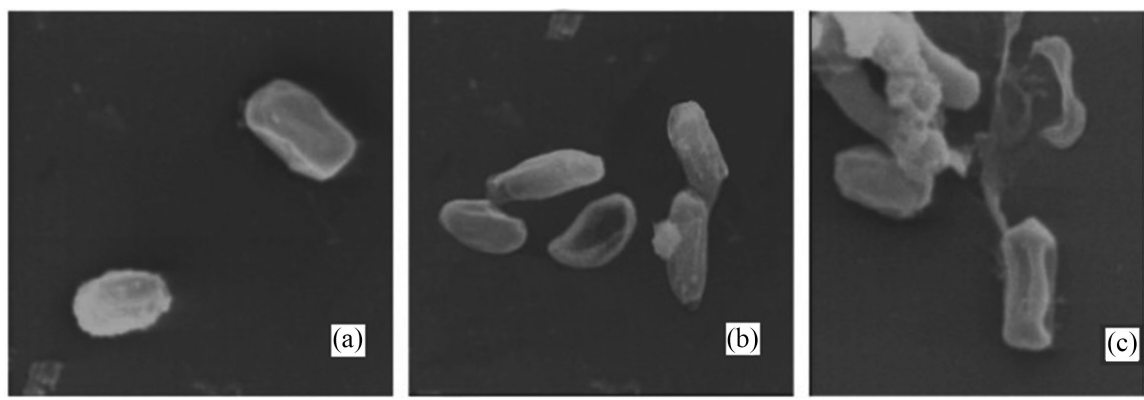

Figure 5. Scanning electron microscope (SEM) images of $B$. subtilis spores under optimal conditions in different processes: (a) Unexposed, (b) $\mathrm{H}_{2} \mathrm{O}_{2}$ /ferrate and (c) $\mathrm{UV} / \mathrm{H}_{2} \mathrm{O}_{2}$ /ferrate [52].

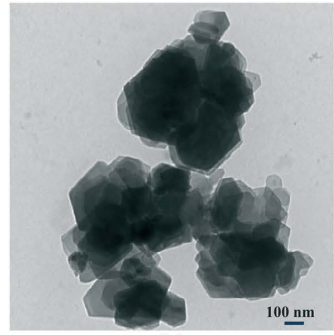

(a)

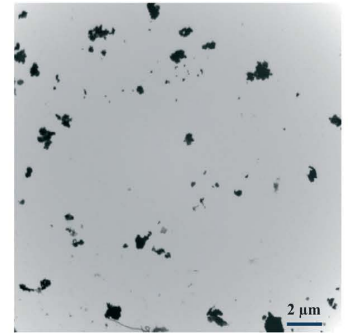

(b)

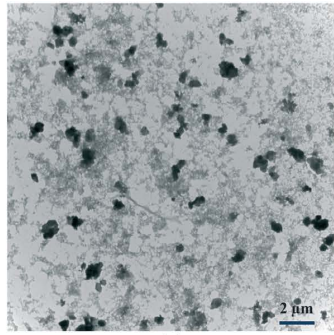

(c)

Figure 6. TEM images of particles in simulated natural water: (a) and (b) kaolin particles suspended in water before $\mathrm{Fe}(\mathrm{VI})$ coagulation; and (c) kaolin particles incorporated into ferrate(VI)-induced iron precipitates $(3.0 \mathrm{mg} / \mathrm{L} \mathrm{Fe}(\mathrm{VI}))(\mathrm{pH} 7.5 ; \mathrm{DOC}=2.00 \mathrm{mg} / \mathrm{L}$; and initial turbidity $=25.00 \mathrm{NTU})[59]$. 


\section{Simultaneous Action of Ferrate as a Coagulant and Disinfectant}

Barışçı [68] tested the performance of ferrate(IV) prepared electrochemically [69] [70] [71] on both the decomposition of humic acid (HA) [72] [73] and the elimination of $E$. coli. In order to guarantee a total demobilization of $E$. coli, $>1.5$ $\mathrm{mg} / \mathrm{L}$ ferrate(VI) concentration has to be injected for only E. coli [74] holding samples. For only HA carrying sample, 60\% DOC elimination was reached with $25 \mathrm{mg} / \mathrm{L}$ ferrate(VI). Ferrate(VI) was observed to be more performant at initial $\mathrm{pH}$ of 7. For HA/E. coli holding samples, ferrate(VI) concentration must be elevated to $260 \mathrm{mg} / \mathrm{L}$ for total demobilization of $E$. coli. Specific UV absorbance (SUVA) values of raw samples illustrated that the samples mainly contain high molecular weight and high hydrophobicity [75] [76] [77] [78]. Following the ferrate(VI) application; whereas almost all hydrophobic fraction was eliminated, a little fraction of the hydrophilic part was also eliminated for only HA holding sample. Nevertheless, for treated HA/E coli carrying sample, the aromatic decrease happened; however, lower and higher molecular weights of NOM remain in the solution in the existence of bacteria. The electro-synthesized ferrate(VI) reduced the trihalomethane formation potential. The remaining total iron concentration was $1.14 \mathrm{mg} / \mathrm{L}$ at $1 \mathrm{~min}$ of residence period and then remained stable. This signifies that ferrate(VI) was consumed as soon as it was injected and reduced to $\mathrm{Fe}^{3+} / \mathrm{Fe}^{2+}$.

\section{Modelling Ferrate(IV) Disinfection}

Elnakar and Buchanan [79] examined the action of fast mixing [80] on the rate of potassium ferrate(VI) decomposition and disinfection [81] [82] [83] in bypass wastewaters from extreme wet weather flow events. First-order, second-order, and double exponential models were fit to the potassium ferrate(VI) exhaustion data, and the double exponential model was able to represent the potassium ferrate(VI) decomposition in all circumstances with an elevated coefficient of determination and low mean square error. Further, they examined Chick-Watson and Hom models, and both fit the E. coli disinfection [84] [85] findings. The rates of potassium ferrate(VI) exhaustion and disinfection [86] obtained from the models were more elevated employing 500 - $1000 \mathrm{rpm}$ rapid mixing velocities than they were when magnetic stirrer mixing was employed for the same initial injection and wastewater sample. There was no important augmentation in the potassium ferrate(VI) exhaustion or disinfection [87] rates with the elevation of the rapid mixing velocities from 500 to $1000 \mathrm{rpm}$ which discovered that the reactions were kinetically controlled. The coagulation potential of potassium ferrate(VI) improved the sedimentation capacity and participated nearly identical as the chemical disinfection potential to the global E. coli elimination. Elnakar and Buchanan [79] concluded that potassium ferrate(VI) may be applied in present plants that mix coagulants to ameliorate primary sedimentation, yet potassium ferrate(VI) may furnish both disinfection [88] and coagulation at lower mixing velocities. 


\section{Dares and Future Trends}

In the face of the considerable performance of ferrate at disinfecting water, scarce publications have given data about its usage or evaluated more kinetic, upscaling, or mechanistic indicators. Additional investigation is necessitated to consistently define many obscure features and deductions for their utilization in treating water [9].

As an illustration, little is recognized concerning the influences of the components of the water employed in ferrate disinfection methods. Even though it has been proposed that ferrate can diminish TOC and bacterial charge simultaneously, there are no publications about the impacts that diverse water components-like ions (such as chloride, carbonate, phosphate) or the existence of nitrogen- or phosphorus-related compounds (such as nitrate and nitrite)—might possess on its performance in disinfection techniques [9].

Utilizing ferrates tested here to demobilize greatly resistant microbes (like helminthes eggs and bacterial or fungal spores) is a different domain in which no accounts have been issued [9]. Employing greatly resistant microbes in a conservative model for water disinfection is very significant to guarantee the treatment of secure potable water even in regions where pathogens like Giardia cysts or Cryptosporidium parvum oocysts may make a danger to consumers if the adequate precautions for safe potable water are not followed. Moreover, their application for demobilizing else nonpathogenic but very significant microorganisms in water (like harmful algal blooms, phytopathogens, and aquatic invasive species) remains an investigation domain that needs focus.

The capacity of ferrates to function as a coagulant following the oxidation stage [89] gives an extremely motivating post-treatment potential. The ferrates' elevated performance and utilization as a green element for water treatment [90] [91] [92] [93] propose that these techniques remain greatly convenient for usage as pre- or post-treatment in traditional wastewater plants [9].

\section{Conclusions}

The main points drawn from this work may be given as:

1) Ferrates were tested for their utilization in disinfecting water. Ferrates displayed important implementations for demobilizing frequent water-related microorganisms, as well as viruses and diverse pathogens. Ferrates were also illustrated to be greatly cost-effective for disinfecting water since both may be employed more than once in the treatment procedure and have been mentioned to possess comparatively low synthesis costs. Nevertheless, more study is necessitated for presenting new materials and techniques that can enhance the findings published yet. There is a requirement for more technical ways that can give knowledge beyond the lab scale and let evaluations of the aptness of employing iron-based materials for pilot- or full-scale usages in water disinfection methods [9].

2) Ferrate(VI) allows a novel emergency water treatment design for disas- 
ter-affected populations through the repercussions of natural disasters, through the concurrent and efficient elimination of microbial and chemical pollutants. The ferrate(VI) injection is a fundamental parameter as it influences the elimination performances of different pollutants and touches the size distributions of iron and metal/metalloid contaminants following ferrate(VI) degradation [43].

3) Ferrate(VI) coagulates colloids through sweep coagulation under drinking water treatment-related circumstances. Featured from conventional coagulation, coagulation via ferrate(VI) progressively forms iron flocs holding amorphous and crystalline iron oxides in water. Meantime, ferrate(VI) oxidation decomposes NOM to promote particle aggregation. Efficient ferrate(VI) coagulation, integrated with ferrate(VI) oxidation, authorizes a dual-pathway treatment to remedy numerous contaminants for supporting water supply sustainability [59]. Disinfection action occurs simultaneously with oxidizing and coagulating roles. This makes ferrate(IV) as well-known a multi-disciplinary agent [79].

\section{Conflicts of Interest}

The authors declare no conflicts of interest regarding the publication of this paper.

\section{References}

[1] Ghernaout, D. (2017) The Holy Koran Revelation: Iron Is a "Sent Down" Metal. American Journal of Environmental Protection, 6, 101-104. https://doi.org/10.11648/j.ajep.20170604.14

[2] Irki, S., Ghernaout, D., Naceur, M.W., Alghamdi, A. and Aichouni, M. (2018) Decolorization of Methyl Orange (MO) by Electrocoagulation (EC) Using Iron Electrodes under a Magnetic Field (MF). II. Effect of Connection Mode. World Journal of Applied Chemistry, 3, 56-64. https://doi.org/10.11648/j.wjac.20180302.13

[3] Ghernaout, D. and Elboughdiri, N. (2019) Iron Electrocoagulation Process for Disinfecting Water-A Review. Applied Engineering, 3, 154-158.

[4] Ghernaout, D., Ghernaout, B. and Boucherit, A. (2008) Effect of pH on Electrocoagulation of Bentonite Suspensions in Batch Using Iron Electrodes. Journal of Dispersion Science and Technology, 29, 1272-1275. https://doi.org/10.1080/01932690701857483

[5] Ghernaout, D., Ghernaout, B., Boucherit, A., Naceur, M.W., Khelifa, A. and Kellil, A. (2009) Study on Mechanism of Electrocoagulation with Iron Electrodes in Idealised Conditions and Electrocoagulation of Humic Acids Solution in Batch Using Aluminium Electrodes. Desalination and Water Treatment, 8, 91-99. https://doi.org/10.5004/dwt.2009.668

[6] Belhout, D., Ghernaout, D., Djezzar-Douakh, S. and Kellil, A. (2010) Electrocoagulation of a Raw Water of Ghrib Dam (Algeria) in Batch Using Iron Electrodes. Desalination and Water Treatment, 16, 1-9. https://doi.org/10.5004/dwt.2010.1081

[7] Ghernaout, D., Irki, S. and Boucherit, A. (2014) Removal of $\mathrm{Cu}^{2+}$ and $\mathrm{Cd}^{2+}$, and Humic Acid and Phenol by Electrocoagulation Using Iron Electrodes. Desalination and Water Treatment, 52, 3256-3270.

https://doi.org/10.1080/19443994.2013.852484

[8] Irki, S., Ghernaout, D. and Naceur, M.W. (2017) Decolourization of Methyl Orange 
(MO) by Electrocoagulation (EC) Using Iron Electrodes under a Magnetic Field (MF). Desalination and Water Treatment, 79, 368-377. https://doi.org/10.5004/dwt.2017.20797

[9] Ramírez-Sánchez, I.M. and Bandala, E.R. (2016) Chap. 6. Use of Ferrate and Ferrites for Water Disinfection. In: Sharma, V.K., Doong, R., Kim, H., Varma, R.S. and Dionysiou, D.D., Eds., Ferrites and Ferrates. Chemistry and Applications in Sustainable Energy and Environmental Remediation, Vol. 1238, ACS Symposium Series, American Chemical Society, Washington DC, 145-159.

https://doi.org/10.1021/bk-2016-1238.ch006

[10] Ghernaout, D. and Naceur, M.W. (2011) Ferrate(VI): In Situ Generation and Water Treatment-A Review. Desalination and Water Treatment, 30, 319-332. https://doi.org/10.5004/dwt.2011.2217

[11] Ghernaout, D., Ghernaout, B. and Naceur, M.W. (2011) Embodying the Chemical Water Treatment in the Green Chemistry-A Review. Desalination, 271, 1-10. https://doi.org/10.1016/j.desal.2011.01.032

[12] Alig, C., Daly, L., Huban, C. and Casson, L. (2011) Ferrate versus Chlorine Disinfection: Disinfection By-Product Reduction and Other Benefits. Proceedings of the Water Environment Federation, 3, 350-355.

[13] Ghernaout, D., Al-Ghonamy, A.I., Boucherit, A., Ghernaout, B., Naceur, M.W., Ait Messaoudene, N., Aichouni, M., Mahjoubi, A.A. and Elboughdiri, N.A. (2015) Brownian Motion and Coagulation Process. American Journal of Environmental Protection, 4, 1-15. https://doi.org/10.11648/j.ajeps.s.2015040501.11

[14] Ghernaout, D., Al-Ghonamy, A.I., Naceur, M.W., Boucherit, A., Ait Messaoudene, N., Aichouni, M., Mahjoubi, A.A. and Elboughdiri, N.A. (2015) Controlling Coagulation Process: From Zeta Potential to Streaming Potential. American Journal of Environmental Protection, 4, 16-27. https://doi.org/10.11648/j.ajeps.s.2015040501.12

[15] Ghernaout, D., Al-Ghonamy, A.I., Ait Messaoudene, N., Aichouni, M., Naceur, M.W., Benchelighem, F.Z. and Boucherit, A. (2015) Electrocoagulation of Direct Brown 2 (DB) and BF Cibacete Blue (CB) Using Aluminum Electrodes. Separation Science and Technology, 50, 1413-1420. https://doi.org/10.1080/01496395.2014.982763

[16] Cho, M., Lee, Y., Choi, W., Chung, H. and Yoon, J. (2006) Study on Fe(VI) Species as a Disinfectant: Quantitative Evaluation and Modeling for Inactivating Escherichia coli. Water Research, 40, 3580-3586. https://doi.org/10.1016/j.watres.2006.05.043

[17] Jiang, J.-Q. (2014) Advances in the Development and Application of Ferrate(VI) for Water and Wastewater Treatment. Journal of Chemical Technology \& Biotechnology, 89, 165-177. https://doi.org/10.1002/jctb.4214

[18] Gombos, E., Felföldi, T., Barkács, K., Vértes, C., Vajna, B. and Záray, G. (2012) Ferrate Treatment for Inactivation of Bacterial Community in Municipal Secondary Effluent. Bioresource Technology, 107, 116-121. https://doi.org/10.1016/j.biortech.2011.12.053

[19] Zhou, S., Shao, Y., Gao, N., Zhu, S., Li, L., Deng, J. and Zhu, M. (2014) Removal of Microcystis aeruginosa by Potassium Ferrate(VI): Impacts on Cells Integrity, Intracellular Organic Matter Release and Disinfection By-Products Formation. Chemical Engineering Journal, 251, 304-309. https://doi.org/10.1016/j.cej.2014.04.081

[20] Ling, F., Wang, J.G., Liu, Q.F., Li, M., Ye, L.T. and Gong, X.N. (2010) Prevention of Ichthyophthirius multifiliis Infestation in Goldfish (Carassius auratus) by Potas- 
sium Ferrate(VI) Treatment. Veterinary Parasitology, 168, 212-216.

https://doi.org/10.1016/j.vetpar.2009.11.009

[21] Dong, F., Liu, J., Li, C., Lin, Q., Zhang, T., Zhang, K. and Sharma, V.K. (2019) Ferrate(VI) Pre-Treatment and Subsequent Chlorination of Blue-Green Algae: Quantification of Disinfection Byproducts. Environment International, 133, Article ID: 105195. https://doi.org/10.1016/j.envint.2019.105195

[22] Hu, L., Page, M.A., Sigstam, T., Kohn, T., Mariñas, B.J. and Strathmann, T.J. (2012) Inactivation of Bacteriophage MS2 with Potassium Ferrate(VI). Environmental Science \& Technology, 46, 12079-12087. https://doi.org/10.1021/es3031962

[23] Jiang, J.-Q. (2007) Research Progress in the Use of Ferrate(VI) for the Environmental Remediation. Journal of Hazardous Materials, 146, 617-623. https://doi.org/10.1016/j.jhazmat.2007.04.075

[24] Barbeau, B., Huffman, D., Mysore, C., Desjardins, R. and Prevost, M. (2004) Examination of Discrete and Confounding Effects of Water Quality Parameters during the Inactivation of MS2 Phages and Bacillus subtilis Spores with Free Chlorine. Journal of Environmental Engineering and Science, 3, 255-268. https://doi.org/10.1139/s04-002

[25] Sharma, V.K. (2002) Potassium Ferrate(VI): An Environmentally Friendly Oxidant. Advances in Environmental Research, 6, 143-156. https://doi.org/10.1016/S1093-0191(01)00119-8

[26] Hu, L., Martin, H.M., Arce-Bulted, O., Sugihara, M.N., Keating, K.A. and Strathmann, T.J. (2008) Oxidation of Carbamazepine by $\mathrm{Mn}$ (VII) and $\mathrm{Fe}(\mathrm{VI})$ : Reaction Kinetics and Mechanism. Environmental Science \& Technology, 43, 509-515. https://doi.org/10.1021/es8023513

[27] Li, C., Li, X.Z. and Graham, N. (2005) A Study of the Preparation and Reactivity of Potassium Ferrate. Chemosphere, 61, 537-543. https://doi.org/10.1016/j.chemosphere.2005.02.027

[28] Sharma, V.K., Smith, J.O. and Millero, F.J. (1997) Ferrate(VI) Oxidation of Hydrogen Sulfide. Environmental Science \& Technology, 31, 2486-2491. https://doi.org/10.1021/es960755z

[29] Ghernaout, D., Al-Ghonamy, A.I., Naceur, M.W., Ait Messaoudene, N. and Aichouni, M. (2014) Influence of Operating Parameters on Electrocoagulation of C.I. Disperse Yellow 3. Journal of Electrochemical Science and Engineering, 4, 271-283. https://doi.org/10.5599/jese.2014.0065

[30] Ghernaout, D., Al-Ghonamy, A.I., Irki, S., Grini, A., Naceur, M.W., Ait Messaoudene, N. and Aichouni, M. (2014) Decolourization of Bromophenol Blue by Electrocoagulation Process. Trends in Chemical Engineering, 15, 29-39.

[31] Gan, W., Sharma, V.K., Zhang, X., Yang, L. and Yang, X. (2015) Investigation of Disinfection Byproducts Formation in Ferrate(VI) Pre-Oxidation of NOM and Its Model Compounds Followed by Chlorination. Journal of Hazardous Materials, 292, 197-204. https://doi.org/10.1016/j.jhazmat.2015.02.037

[32] Sharma, V.K., Zboril, R. and McDonald, T.J. (2014) Formation and Toxicity of brominated Disinfection Byproducts during Chlorination and Chloramination of Water: A Review. Journal of Environmental Science and Health, Part B, 49, 212-228. https://doi.org/10.1080/03601234.2014.858576

[33] Ghernaout, D., Alghamdi, A., Aichouni, M. and Touahmia, M. (2018) The Lethal Water Tri-Therapy: Chlorine, Alum, and Polyelectrolyte. World Journal of Applied Chemistry, 3, 65-71. https://doi.org/10.11648/j.wjac.20180302.14

[34] Yang, X., Guo, W., Zhang, X., Chen, F., Ye, T. and Liu, W. (2013) Formation of 
Disinfection By-Products after Pre-Oxidation with Chlorine Dioxide or Ferrate. Water Research, 47, 5856-5864. https://doi.org/10.1016/j.watres.2013.07.010

[35] Ghernaout, D., Elboughdiri, N. and Al Arni, S. (2019) Water Reuse (WR): Dares, Restrictions, and Trends. Applied Engineering, 3, 159-170.

[36] Ghernaout, D., Elboughdiri, N. and Ghareba, S. (2019) Drinking Water Reuse: One-Step Closer to Overpassing the "Yuck Factor". Open Access Library Journal, 6, e5895. https://doi.org/10.4236/oalib.1105895

[37] Ghernaout, D. (2019) Reviviscence of Biological Wastewater Treatment-A Review. Applied Engineering, 3, 46-55.

[38] Al Arni, S., Amous, J. and Ghernaout, D. (2019) On the Perspective of Applying of a New Method for Wastewater Treatment Technology: Modification of the Third Traditional Stage with Two Units, One by Cultivating Microalgae and Another by Solar Vaporization. International Journal of Environmental Sciences \& Natural Resources, 16, Article ID: 555934. https://doi.org/10.19080/IJESNR.2019.16.555934

[39] Ghernaout, D., Alshammari, Y. and Alghamdi, A. (2018) Improving Energetically Operational Procedures in Wastewater Treatment Plants. International Journal of Advanced and Applied Sciences, 5, 64-72. https://doi.org/10.21833/ijaas.2018.09.010

[40] Ghernaout, D. (2018) Increasing Trends towards Drinking Water Reclamation from Treated Wastewater. World Journal of Applied Chemistry, 3, 1-9. https://doi.org/10.11648/j.wjac.20180301.11

[41] Ghernaout, D. (2017) Water Reuse (WR): The Ultimate and Vital Solution for Water Supply Issues. International Journal of Sustainable Development Research, 3, 36-46. https://doi.org/10.11648/j.ijsdr.20170304.12

[42] Bandala, E.R., Miranda, J., Beltran, M., Vaca, M., Lopez, R. and Torres, L.G. (2009) Wastewater Disinfection and Organic Matter Removal Using Ferrate(VI) Oxidation. Journal of Water and Health, 7, 507-513. https://doi.org/10.2166/wh.2009.003

[43] Cui, J., Zheng, L. and Deng, Y. (2018) Emergency Water Treatment with Ferrate(VI) in Response to Natural Disasters. Environmental Science: Water Research \& Technology, 4, 359-368. https://doi.org/10.1039/C7EW00467B

[44] Irki, S., Ghernaout, D., Naceur, M.W., Alghamdi, A. and Aichouni, M. (2018) Decolorizing Methyl Orange by Fe-Electrocoagulation Process-A Mechanistic Insight. International Journal of Environmental Chemistry, 2, 18-28. https://doi.org/10.11648/j.ijec.20180201.14

[45] Ghernaout, D., Alghamdi, A. and Ghernaout, B. (2019) Electrocoagulation Process: A Mechanistic Review at the Dawn of Its Modeling. Journal of Environmental Science and Allied Research, 2, 22-38. https://doi.org/10.29199/2637-7063/ESAR-201019

[46] Ghernaout, D. (2013) The Best Available Technology of Water/Wastewater Treatment and Seawater Desalination: Simulation of the Open Sky Seawater Distillation. Green and Sustainable Chemistry, 3, 68-88. https://doi.org/10.4236/gsc.2013.32012

[47] Ghernaout, D. (2017) Water Treatment Chlorination: An Updated Mechanistic Insight Review. Chemistry Research Journal, 2, 125-138.

[48] Ghernaout, D. (2018) Magnetic Field Generation in the Water Treatment Perspectives: An Overview. International Journal of Advanced and Applied Sciences, 5, 193-203. https://doi.org/10.21833/ijaas.2018.01.025

[49] Ghernaout, D. (2018) Electrocoagulation Process: Achievements and Green Perspectives. Colloid and Surface Science, 3, 1-5. https://doi.org/10.11648/j.css.20180301.11 
[50] Ghernaout, D., El-Wakil, A., Alghamdi, A., Elboughdiri, N. and Mahjoubi, A. (2018) Membrane Post-Synthesis Modifications and How It Came about. International Journal of Advanced and Applied Sciences, 5, 60-64. https://doi.org/10.21833/ijaas.2018.02.010

[51] Ghernaout, D. (2017) Entropy in the Brownian Motion (BM) and Coagulation Background. Colloid and Surface Science, 2, 143-161.

[52] Matin, A.R., Yousefzadeh, S., Ahmadi, E., Mahvi, A., Alimohammadi, M., Aslani, H. and Nabizadeh, R. (2018) A Comparative Study of the Disinfection Efficacy of $\mathrm{H}_{2} \mathrm{O}_{2} /$ Ferrate and $\mathrm{UV} / \mathrm{H}_{2} \mathrm{O}_{2} /$ Ferrate Processes on Inactivation of Bacillus subtilis Spores by Response Surface Methodology for Modeling and Optimization. Food and Chemical Toxicology, 116, 129-137. https://doi.org/10.1016/j.fct.2018.04.002

[53] Ghernaout, D. and Ghernaout, B. (2010) From Chemical Disinfection to Electrodisinfection: The Obligatory Itinerary? Desalination and Water Treatment, 16, 156-175. https://doi.org/10.5004/dwt.2010.1085

[54] Boucherit, A., Moulay, S., Ghernaout, D., Al-Ghonamy, A.I., Ghernaout, B., Naceur, M.W., Ait Messaoudene, N., Aichouni, M., Mahjoubi, A.A. and Elboughdiri, N.A. (2015) New Trends in Disinfection By-Products Formation upon Water Treatment. Journal of Research \& Developments in Chemistry, 2015, Article ID: 628833. https://doi.org/10.5171/2015.628833

[55] Ghernaout, D. (2017) Microorganisms' Electrochemical Disinfection Phenomena. EC Microbiology, 9, 160-169.

[56] Ghernaout, D. (2018) Disinfection and DBPs Removal in Drinking Water Treatment: A Perspective for a Green Technology. International Journal of Advanced and Applied Sciences, 5, 108-117. https://doi.org/10.21833/ijaas.2018.02.018

[57] Saiba, A., Kourdali, S., Ghernaout, B. and Ghernaout, D. (2010) In Desalination, from 1987 to 2009, the Birth of a New Seawater Pretreatment Process: Electrocoagulation-An Overview. Desalination and Water Treatment, 16, 201-217. https://doi.org/10.5004/dwt.2010.1094

[58] Ghernaout, D. (2017) Environmental Principles in the Holy Koran and the Sayings of the Prophet Muhammad. American Journal of Environmental Protection, 6, 75-79. https://doi.org/10.11648/j.ajep.20170603.13

[59] Lv, D., Zheng, L., Zhang, H. and Deng, Y. (2018) Coagulation of Colloidal Particles with Ferrate(VI). Environmental Science: Water Research \& Technology, 4, 701-710. https://doi.org/10.1039/C8EW00048D

[60] Ghernaout, D. and Ghernaout, B. (2012) Sweep Flocculation as a Second Form of Charge Neutralisation-A Review. Desalination and Water Treatment, 44, 15-28. https://doi.org/10.1080/19443994.2012.691699

[61] Ghernaout, D., Laribi, C., Alghamdi, A., Ghernaout, B., Ait Messaoudene, N. and Aichouni, M. (2018) Decolorization of BF Cibacete Blue (CB) and Red Solophenyle 3BL (RS) Using Aluminum Sulfate and Ferric Chloride. World Journal of Applied Chemistry, 3, 32-40. https://doi.org/10.11648/j.wjac.20180302.11

[62] Ghernaout, D. (2014) The Hydrophilic/Hydrophobic Ratio vs. Dissolved Organics Removal by Coagulation-A Review. Journal of King Saud University: Science, 26, 169-180. https://doi.org/10.1016/j.jksus.2013.09.005

[63] Ghernaout, D., Moulay, S., Ait Messaoudene, N., Aichouni, M., Naceur, M.W. and Boucherit, A. (2014) Coagulation and Chlorination of NOM and Algae in Water Treatment: A Review. International Journal of Environmental Monitoring and Analysis, 2, 23-34. https://doi.org/10.11648/j.ijema.s.2014020601.14

[64] Ghernaout, D., Benblidia, C. and Khemici, F. (2015) Microalgae Removal from 
Ghrib Dam (Ain Defla, Algeria) Water by Electroflotation Using Stainless Steel Electrodes. Desalination and Water Treatment, 54, 3328-3337. https://doi.org/10.1080/19443994.2014.907749

[65] Ghernaout, D. (2019) Electrocoagulation Process for Microalgal Biotechnology-A Review. Applied Engineering, 3, 85-94.

[66] Ghernaout, B., Ghernaout, D. and Saiba, A. (2010) Algae and Cyanotoxins Removal by Coagulation/Flocculation: A Review. Desalination and Water Treatment, 20, 133-143. https://doi.org/10.5004/dwt.2010.1202

[67] Ghernaout, D. and Ghernaout, B. (2012) On the Concept of the Future Drinking Water Treatment Plant: Algae Harvesting from the Algal Biomass for Biodiesel Production-A Review. Desalination and Water Treatment, 49, 1-18. https://doi.org/10.1080/19443994.2012.708191

[68] Barışçı, S. (2017) The Disinfection and Natural Organic Matter Removal Performance of Electro-Synthesized Ferrate(VI). Journal of Water Process Engineering, 20, 84-89. https://doi.org/10.1016/j.jwpe.2017.10.005

[69] Ghernaout, D., Naceur, M.W. and Ghernaout, B. (2011) A Review of Electrocoagulation as a Promising Coagulation Process for Improved Organic and Inorganic Matters Removal by Electrophoresis and Electroflotation. Desalination and Water Treatment, 28, 287-320. https://doi.org/10.5004/dwt.2011.1493

[70] Ghernaout, D. and Ghernaout, B. (2011) On the Controversial Effect of Sodium Sulphate as Supporting Electrolyte on Electrocoagulation Process: A Review. Desalination and Water Treatment, 27, 243-254. https://doi.org/10.5004/dwt.2011.1983

[71] Ghernaout, D., Naceur, M.W. and Aouabed, A. (2011) On the Dependence of Chlorine By-Products Generated Species Formation of the Electrode Material and Applied Charge during Electrochemical Water Treatment. Desalination, 270, 9-22. https://doi.org/10.1016/j.desal.2011.01.010

[72] Ghernaout, D., Mariche, A., Ghernaout, B. and Kellil, A. (2010) Electromagnetic Treatment-Bi-Electrocoagulation of Humic Acid in Continuous Mode Using Response Surface Method for Its Optimization and Application on Two Surface Waters. Desalination and Water Treatment, 22, 311-329. https://doi.org/10.5004/dwt.2010.1120

[73] Ghernaout, D., Ghernaout, B., Saiba, A., Boucherit, A. and Kellil, A. (2009) Removal of Humic Acids by Continuous Electromagnetic Treatment Followed by Electrocoagulation in Batch Using Aluminium Electrodes. Desalination, 239, 295-308. https://doi.org/10.1016/j.desal.2008.04.001

[74] Ghernaout, D., Badis, A., Ghernaout, B. and Kellil, A. (2008) Application of Electrocoagulation in Escherichia coli Culture and Two Surface Waters. Desalination, 219, 118-125. https://doi.org/10.1016/j.desal.2007.05.010

[75] Ghernaout, D., Badis, A., Braikia, G., Matâam, N., Fekhar, M., Ghernaout, B. and Boucherit, A. (2017) Enhanced Coagulation for Algae Removal in a Typical Algeria Water Treatment Plant. Environmental Engineering and Management Journal, 16, 2303-2315. https://doi.org/10.30638/eemj.2017.238

[76] Djezzar, S., Ghernaout, D., Cherifi, H., Alghamdi, A., Ghernaout, B. and Aichouni, M. (2018) Conventional, Enhanced, and Alkaline Coagulation for Hard Ghrib Dam (Algeria) Water. World Journal of Applied Chemistry, 3, 41-55. https://doi.org/10.11648/j.wjac.20180302.12

[77] Kellali, Y. and Ghernaout, D. (2019) Physicochemical and Algal Study of Three Dams (Algeria) and Removal of Microalgae by Enhanced Coagulation. Applied Engineering, 3, 56-64. 
[78] Ghernaout, D., Ghernaout, B. and Kellil, A. (2009) Natural Organic Matter Removal and Enhanced Coagulation as a Link between Coagulation and Electrocoagulation. Desalination and Water Treatment, 2, 203-222. https://doi.org/10.5004/dwt.2009.116

[79] Elnakar, H. and Buchanan, I. (2019) The Role of Mixing in Potassium Ferrate(VI) Consumption Kinetics and Disinfection of Bypass Wastewater. Journal of Environmental Management, 231, 515-523. https://doi.org/10.1016/j.jenvman.2018.10.076

[80] Ghernaout, D. and Boucherit, A. (2015) Review of Coagulation's Rapid Mixing for NOM Removal. Journal of Research \& Developments in Chemistry, 2015, Article ID: 926518. https://doi.org/10.5171/2015.926518

[81] Ghernaout, D., Aichouni, M. and Touahmia, M. (2019) Mechanistic Insight into Disinfection by Electrocoagulation-A Review. Desalination and Water Treatment, 141, 68-81. https://doi.org/10.5004/dwt.2019.23457

[82] Ghernaout, D., Alghamdi, A. and Ghernaout, B. (2019) Microorganisms' Killing: Chemical Disinfection vs. Electrodisinfection. Applied Engineering, 3, 13-19.

[83] Ghernaout, D. (2019) Disinfection via Electrocoagulation Process: Implied Mechanisms and Future Tendencies. EC Microbiology, 15, 79-90.

[84] Ghernaout, D. (2019) Greening Electrocoagulation Process for Disinfecting Water. Applied Engineering, 3, 27-31.

[85] Ghernaout, D. and Elboughdiri, N. (2019) Electrocoagulation Process Intensification for Disinfecting Water-A Review. Applied Engineering, 3, 140-147.

[86] Ghernaout, D. (2019) Electrocoagulation and Electrooxidation for Disinfecting Water: New Breakthroughs and Implied Mechanisms. Applied Engineering, 3, 125-133.

[87] Ghernaout, D. (2019) Virus Removal by Electrocoagulation and Electrooxidation: New Findings and Future Trends. Journal of Environmental Science and Allied Research, 2019, 85-90. https://doi.org/10.29199/2637-7063/ESAR-202024

[88] Ghernaout, D., Touahmia, M. and Aichouni, M. (2019) Disinfecting Water: Electrocoagulation as an Efficient Process. Applied Engineering, 3, 1-12.

[89] Ghernaout, D. (2013) Advanced Oxidation Phenomena in Electrocoagulation Process: A Myth or a Reality? Desalination and Water Treatment, 51, 7536-7554. https://doi.org/10.1080/19443994.2013.792520

[90] Ghernaout, D., Aichouni, M. and Alghamdi, A. (2018) Applying Big Data (BD) in Water Treatment Industry: A New Era of Advance. International Journal of Advanced and Applied Sciences, 5, 89-97. https://doi.org/10.21833/ijaas.2018.03.013

[91] Ghernaout, D., Simoussa, A., Alghamdi, A., Ghernaout, B., Elboughdiri, N., Mahjoubi, A., Aichouni, M. and El-Wakil, A.E.A. (2018) Combining Lime Softening with Alum Coagulation for Hard Ghrib Dam Water Conventional Treatment. International Journal of Advanced and Applied Sciences, 5, 61-70. https://doi.org/10.21833/ijaas.2018.05.008

[92] Alshammari, Y., Ghernaout, D., Aichouni, M. and Touahmia, M. (2018) Improving Operational Procedures in Riyadh's (Saudi Arabia) Water Treatment Plants Using Quality Tools. Applied Engineering, 2, 60-71.

[93] Ghernaout, D. (2019) Greening Cold Fusion as an Energy Source for Water Treatment Distillation-A Perspective. American Journal of Quantum Chemistry and Molecular Spectroscopy, 3, 1-5. 